УДК 22.01

821.163.41(091)-13:398

https://doi.org/10.18485/msc50_vuk_trsic.2021.ch16

Љиљана Пешикан-Љуштановић

\title{
„ПОШЉЕДЊЕ ВРИЈЕМЕ” У БИБЛИЈИ И ПЕСМАМА ИЗ ВУКОВИХ ЗБИРКИ ${ }^{1}$
}

У једном броју епских песама Вукових збирки јављају се есхатолошки мотиви последњег времена. Однос ових песама према Библији разматраће се у овом раду на плану садржине, дакле са становишта заједничких или слично обрађених мотива, и на плану значења, пре свега кроз разматрање поимања времена. ${ }^{2}$

По обради мотива последњег времена испитиване песме могу се поделити у две групе. Прву би чиниле оне у којима се пропаст света смешта у митско време стварања света и мотивише људским огрешењима, а другу оне у којима се овај мотив историзује, везује за конкретна збивања и, углавном, не мотивише почињеним греховима.

Првој групи тако припадају варијанте песме Свеци благо дијеле (СНП II, 1 и 2), у којима је остварен специфичан слој космолошког и есхатолошког мита: причи о подели моћи међу светитељима и хармонизовању неба супротставља се безакоње и хаос на земљи, што доводи до божје казне, којом се успоставља нарушени поредак. Овој групи припадала би и песма Свещи кажъавају грешнике (CHПр II, 2) иако садржи само есхатолошку „причу” - опева људска безакоња, њихово кажњавање и поновно успостављање реда.

1 Овај рад је настао као део истраживања у оквиру пројекта „Проучавање српске књижевности по жанровима”, који се под руководством проф. др Марије Клеут реализује на Филозофском факултету у Новом Саду, уз финансијску помоћ Министарства за науку и технологију Републике Србије.

2 Дакле, без евентуалног разматрања генеричких веза с текстовима средњовековне књижевности и њиховог могућег утицаја. (Види: Откривеније, Цароставник, у: Ђорђе Трифуновић, Азбучник српских средновековних книжевних појмова, Београд, 1974, стр. 212. и 347). 
Сама синтагма „пошљедње вријеме” формулисана је у другој групи песама, у онима које су заокупљене збивањима која непосредно претходе косовском боју, и, по Миодрагу Матицком, чине „особит пролог косовској епопеји". ${ }^{3}$ То су песме Женидба кнеза Лазара (СНП II, 32) и две варијанте песме Зидағе Раванице (СНП II, 36) и у њима је извршена специфична „митологизација историје”, али и „превођење” збивања из космичких у социјалне оквире и конкретизовање митске приче. Исто важи и за песму Почетак буне против дахија (CHП IV, 24).

У обе варијанте песме Свеци благо дијеле и у песми Свеци кажнавају грешнике, опису пропасти претходе описи огрешења којима се могу тражити паралеле у Библији. У првој варијанти песме Свеци благо дијеле (CHП II, 1) прво је нарушавање хијерархије унутар породице:

Не поштује млађи старијега, не слушају ђеца родитеља; родитељи пород погазили...

Томе следи огрешење о кумство и братске односе:

Кум свог кума на судове ћера, и доведе лажљиве свједоке и без вјере, и без чисте душе, и оглоби кума вјенчанога

(..)

а брат брата на мејдан зазива.

И, као најтежи грех, наговештај инцеста:

Ђевер снаси о срамоти ради, а брат сестру сестром не дозива. ${ }^{5}$

Иако су и у трећој књизи Мојсијевој предвиђене смртне казне за онога ко не поштује родитеље, или почини инцест (Трећа књига Мој-

${ }^{3}$ Миодраг Матицки, Поновнице, Типови односа усмене и писане книжевности, Нови Сад, 1989, стр. 64.

${ }^{4}$ Е. М. Мелетински, Поетика мита, превео Јован Јанићијевић, Београд б.г., стр. 226.

${ }^{5}$ Веома слично опева Хесиод огрешења „петога рода” због којих ће „људско племе божански затрти Зеус":

Нит ће бит отац дјеци ни дјеца подобна оцу,

Ни спрам домаћину гост, ни друг према другу добар,

Нит ће браћа бити, као некада, браћа...

(Хезиод, Послови и дани, превео Алберт Базала, Загреб, 1970, стр. 22). 
сијева, 20,9-126), ова градација у песми ипак превасходно одсликава вредносни систем патријархалне заједнице, па се извесна подударања са библијским поимањем греха не морају тумачити искључиво утицајем Старог завета, већ и генезом у сличним социо-културним условима. У Старом и у Новом завету знатна пажња се посвећује и поштовању празника (Трећа књига Мојсијева, 23), а управо огрешења о празник, ред у недељу на Преображење, изазива пропаст у песми Свеци кажюавају грешнике (СНПр II, 2):

Косци косе, жетеоци жању, Бељарице б’јело платно б'јеле и нуз платно за рукаве везу!

Ипак, овде, по свој прилици, не треба тражити непосредан утицај Светог писма. Односно, верујем да се ова песма пре може везивати за оне архаичне предпоставке по којима је важан део хармоније између људи, природе и виших сила поштовање утврђених временских ритмова - поред осталог и поштовање времена које припада одређеном послу, које су у извесном виду баштинили и јудео-хришћански свети списи.

Градација сагрешења у другој варијанти песме Свеци благо дијеле (CHП II, 2) ближа је библијским, посебно старозаветним представама о греху. То пре свега важи за развијање мотива „божјег незаконства”. Примарно је огрешење то што грешници „не моле бога да помогне”, а најтеже је огрешење несветковање светаца, непаљење свеће и неслужење литургије, дакле, напуштање свих основних елемената обредне праксе. Овим „незаконствима” придружује се стереотипна непослушност деце према родитељима и млађих према старијима, као и нарушено кумство, инцест, неслога и парничење међу браћом, овде историјски конкретизовано:

Ђе брат брата по судовим' ћера

И мучи га муках пред Турцима.

Најтежи грех у старозаветној хијерархији јесте идолопоклонство, незнабоштво (Друга књига Мојсијева, 32), нарушавање закона божјег (Пета књига Мојсијева, 28), одрицање да се богу служи „радосна и весела срца” (Пета књига Мојсијева, 28). Из ових огрешења произлазе убиство, инцест, блуд, непослушност, неверност... И у новозаветном Откровењу Јовановом тешки су грешници они који саблажњавају синове Израиљеве „да једу жртве идолске и да се курвају” (Откровење светог Јована Бого-

${ }^{6}$ Свето писмо старога и новога завјета, превео Стари завјет Ђура Даничић, Нови завјет превео Вук Стеф. Караџић, Београд 1955. 
слова 2,14. и 20); идолопоклоници који се „поклањају ђаволима и идолима златнима и сребрним и мједнима и каменима и дрвенима" (Откровење светог Јована Богослова 9,20); и богохулници - што су огрешења из којих произилазе сва друга.

У песмама из друге групе „пошљедње вријеме” се ишчитава или прориче из књига староставних (цароставних) или инџијела, јеванђеља (CHП II, 32; CHП II, 35; CHП II, 36; CHП IV, 24) ${ }^{8}$ - и у њима катастрофи не претходи огрешење, бар не експлицитно формулисано. Тако, на пример, парничење кумова и борба међу браћом, у песми Женидба кнеза Лазара, нису узрок настајања пошљедњег времена, већ његова манифестација. Могуће сагрешење можда се може слутити у спремности Југовића да због породичног поноса и самосвести погубе цара, или, у другој песми истога певача - Урош и Мрнавчевићи (СНП II, 34) - у завади и грабежљивости царева, који „међу се се хоће да поморе”я и чији се сукоб не окончава ни када се по књигама староставним пресуди на коме је царство. Могуће сагрешење се у Рашком Зидағу Раванице (СНП II, 35) формулише као гомилање блага које се не троши на зидање задужбина и потврђивање завета с богом, већ на материјална добра, оличена у хиперболисаној раскоши царичине одеће. Ипак, у овим песмама нема сагрешења која би својом тежином оправдала наступање пошљедњих времена. ${ }^{10}$ Смак се овде не јавља као старозаветна „негативна теофанија” и оличење Јеховиног гнева, ни као коначни суд и крај времена, већ, рекло би се, зато што је тако писано и зато да би Лазар и његови витезови мучеништвом досегли царство небеско.

Само се Вишњићева песма Почетак буне против дахија (CHП IV, 24) издваја управо постојањем јасно формулисаног сагрешења. Објаву последњег времена дахијама из „књига инџијела” ишчитавају хоџе и ваизи, мотивишући његово наступање неопоштовањем завета умирућег цара и насиљем над рајом супротном његовом аманету. Пропаст царства, погибија, пожари и пустош, рушење богомоља, порази и расејање

7 Види: Томо Маретић, Наша народна епика, напомене и поговор Владан Недић, Београд 1966, стр. 321.

${ }^{8}$ Прве две песме су Рашкове, песму Опет зидағе Раванице певао је сељак из Рудничке нахије, а Почетак буне против дахија Филип Вишњић.

9 У овом великашком сукобу Његош је нашао огрешење и кривицу за трагичну судбину српског царства:

Великаши, проклете им душе, на комаде раздробише царство.

${ }^{10}$ Евентуално, изузетак би била песма Урош и Мрғавчевићи, ако прихватимо успостављање интертекстуалног односа између двеју различитих песама. 
- у основи представљају историјску конкретизацију катастрофе којом се завршава један временски циклус - епоха турске владавине и Срби поново „преузимају царство”. „Чудне прилике” које наговештавају преврат у овој песми изразито се подударају са најавом поновног Христовог доласка и краја света у Јеванђељу по Матеју:

„27. Јер као што муња излази од истока и показује се до запада, таки ће бити долазак сина човјечјега. (..)

29. И одмах ће по невољи дани тијех сунце помрачити, и мјесец своју свјетлост изгубити, и звијезде с неба спасти, и силе небеске покренути се.

(Свето јеванђеље по Матеју, 24, 27-29)

Знатно уопштенији је опис пропасти света у песмама Свеци благо дијеле (СНП II, 1 и 2) и Свеци кажнавају грешнике (СНПр II, 2). Запечаћених седам небеса (што непосредно асоцира на Откровење Јованово) изазивају сушу која траје три године (током којих нема „дожда плодовита") и од које пуца земља и помрачују се месец и сунце. Ово, као и огањ с небеса, муње и громови, спада, иначе, у уобичајене казне за нарушавање завета с богом. Нарочито у књигама пророка, али и у Мојсијевим, казне за огрешење бивају: помрачење сунца, месеца и звезда (Књига пророка Језекиља, 32, 6-8), суша и жеђ (Друга књига Мојсијева, 7-12; Пета књига Мојсијева, 28; Књига пророка Исаије, 15,6 и 19). Штавише, и у Старом завету (Прва књига о царевима, 17) суша траје три године, и од ње пуца земља (Књига пророка Јеремије, 14,4). За климатску и космичку катаклизму у песмама су везане болести: срдобоља (CHП II, 1); изгарање од сунца (CHП II, 20 и куга - које изазивају помор и изумирање људи. Овај помор прати пропадање сваког берићета, како земаљског - вина и пшенице (CHП II, 1 и 2), тако и оног у стоци - са света нестају овце и пчеле (CHП II, 2). И Библија обилује сликама болести које су казна за сагрешење. То могу бити слепило, лудило, беснило, шуга, гнојаве красте, црне богиње, пришт, сушица и врућица, али и патња због уједа отровних скакаваца, којима се даје „област на земљи” (Откровење светога Јована Богослова, 9,3). Чести су такође и описи великих помора, а божја казна се јавља и као међусобно убијање грешника (синови Левијеви због идолопоклонства убијају „до три тисуће људи” - својих сродника и пријатеља - Друга књига Мојсијева, 26-29).

Пропадање вина и пшенице и у Библији често симболизује последње време. Вино је у Библији, уз остало, симбол радости и божјих дарова љу- 
дима (у Старом завету) и битан елеменат хришћанске обредне праксе. Због тога се у Библији вином и пшеницом остварује и божји благослов: „Бог ти дао росе небеске, и добре земље и пшенице и вина изобила!” (Прва књига Мојсијева, 27,28) и клетва. Симбол пораза и ропства је виноград из којег онај ко га је садио не пије вина (Пета књига Мојсијева, $28,39)$. Губитак жита, вина и уља или разводњавање вина и обезвређење винограда (Књига пророка Исаије, 1,22), знак су несреће. Пропаст Дамаска, на пример, симболизује се посеченом лозом, а увела лоза је за Језекиља метафора Израиља (Књига пророка Језекиља, 19).

Једнако је развијена симболика жита/хлеба: благословени ће имати хлеба „до ситости” (Трећа књига Мојсијева, 26,5) и претицаће им жита и за просипање; проклетима прети глад и затварање жита - ратом или због гамади. Пропаст усева праћена је, у нашим песмама, пропашћу стоке, посебно оваца, а исти мотив се у неколико наврата јавља и у Библији. (Пета књига Мојсијева, 28; Књига пророка Јеремије, 17)

Управо нестајањем пшенице, пчеле и цвета и људским безакоњем, окарактерисано је пошљедње вријеме у Женидби Кнеза Лазара, док се у обе варијанте Зидаға Раванице као његови знакови побрајају губитак царства и падање под турску власт, насиље, рушење задужбина и градова. Својеврсну паралелу овим визијама представља Лазарево предвиђање будућности у песми О боју косовском (СНПр II, 30) из Вукове рукописне заоставштине. Лазар ту слути будућност рационално, ни основу историјског искуства и без пророчког патоса:

Тешко је једном цару арач скупити,

А камо ли двојици купити;

Ако ћемо дати наша добра Турком,

Нашу ћемо земљу раселити,

Земља ће нам пуста остати...

Симболика битке и рата развијена је и у Новом завету, нарочито у Откровењу Јовановом, али чулно-појавној конкретности слика у песмама о којима говоримо, ближе су старозаветне књиге пророка и Пета књига Мојсијева у којој се у градацији која иде до канибализма слика несрећа ратом пометног и расељеног народа: „Напољу мач, а унутра помор и глад..." (Књига пророка Језекиља, 7,15$)$. Део те пометње јесте и рушење богомоља и градова, какво слуте и наше песме. Јехова прети невернима: „и оборићу градове ваше у пустош, и разорићу светиње ваше” (Трећа књига Мојсијева, 26, 3), или „развалиће зидове твоје и лијепе куће твоје” (Књига пророка Језекиља, 26, 12). Мотив сребра и злата који губе своју примарну вредност и функцију, и доносе пропаст, такође је заједнички 
Вуковим песмама о зидању Раванице и књигама пророка: Исаија каже да је сребро постало троска, а Језекиљ „сребро њихово и злато њихово неће их моћи изабрати у дан гњева Господњега” $(7,19)$.

Брзом царевању и насиљу Турака можемо можда тражити паралелу у слици туђинских ратника: „род земље твоје и сву муку твоју изјешће народ, којег не знаш, и чиниће ти криво и газиће те једнако” (Пета књига Мојсијева, 28,33).

Чулно-конкретна форма слика из Старог завета и придавање религиозне вредности историјским догађајима, какво срећемо у књигама пророка, нису једини разлози што су у овом раду народне песме углавном упоређиване са Старим заветом, иако сам сличне или чак идентичне мотиве могла тражити и у Новом завету - превасходно у Откровењу Јовановом и Јеванђељу по Матеју (Свето јеванђеље по Матеју, 24). То нисам урадила зато што ми се чинило да су разлике између представе о пошљедњем времену у нашим песмама и оне у Откровењу Јовановом и Јеванђељу по Матеју битније од евентуалних мотивских сличности. При томе не мислим само на разлике у њиховој развијености и уобличености, већ пре свега, на битно различит смисао.

Откровење Јованово говори одиста о последњем времену - о крају историје. Реч је о неповратном чину, о коначној хармонизацији и преобликовању света, после којег више није могуће „ослобађање космичких сила хаоса или слабљење космичке структуре"11:

И ноћи тамо неће бити и неће потребовати видјела од жишка, ни видјела сунчанога, јер ће их обасјавати господ Бог; и цароваће ва вијек вијека. (Откровење светог Јована богослова, 22, 5)

C друге стране, слика „пошљедњег времена” у нашим песмама баштини древну митску причу у чијој је основи веровање у нужност периодичног обнављања света - због људских сагрешења, али и због његове оронулости. Свет стари и хаба се, и ова „кружна космологија” ${ }^{2}$, каква се огледа, на пример, у универзално распрострањеном миту о потопу ${ }^{13}$, подразумева уништење опсле којег долази обнављање: у нашим песмама обнавља се безакоњем нарушени завет људи и бога. То се обнављање врши покајањем (CHП II, 1):

${ }_{11}$ Е. М Мелетински, Нав. дело, 228.

${ }_{12}$ Мирча Елијаде, „Када је Израиљ био дете”..., 55. Пре и после потопа, Историја верована и религијских идеја I, Од каменог доба до Елеусинских мистерија, превела Биљана Лукић, Београд, 1991, стр. 146.

${ }_{13}$ Исто. Овај мит се јавља као асирски, месопотамски, кинески, индијски, грчки. 
Што остало, то се покајало

Господина Бога вјеровало.

И осташе божји благослови:

Да не падне леда и снијега

До једанпут у години дана.

Ова погодба, по обећању да више неће бити разорних климатских непогода и поремећаја космичког ритма, подсећа на Јеховин завјет Ноју: „и неће више бити од воде потопа да затре свако тијело” (Прва књига Мојсијева, 9, 15), чији је знак дуга.

Хармонизација односа људи и Бога може се успоставити и молитвом (CHП II, 2):

Тако настаје нов и очишћен свет, који прихвата нове законе и почива на систему вредности опозитном старом свету, али и он је подложан хабању и мора се циклично обнављати.

Зато „пошљедње вријеме”, које наступа с косовским сломом (или по песми Зидаюе Раванице - пре њега) није крај историје већ слом царства, који за оне које погађа има одлике катастрофе, али после којег долази обнављање. Циклус зачет прорицањем књига староставних, окончава се новим пророчанством - опет из светих књига - инџијела, које слуте катастрофу царства на власти и отпочињање новог циклуса.

Можемо претпоставити да је на уобличење песничких слика пошљедњег времена у разматраним песмама Библија вероватно и непосредно и посредно утицала, али и то да овај архајски концепт времена, по коме се свет периодично изнова ствара, а време обнавља - није генерисан из Библије, односно Старог завета, већ би могао бити везан и за древну индоевропску митску причу о смаку и поновном рођењу света.

\section{СКРАЋЕНИЦЕ}

СНП II - Вук Стефановић Караџић, Сриске народне пјесме, Скупио их и на свијет издао..., Кюига друга у којој су пјесме јуначке најстарије, у Бечу 1845. Наводи по: Сабрана дела Вука Караиића, књига пета, приредила Радмила Пешић, Просвета, Београд, 1988.

CHП IV - Вук Стефановић Караџић, Српске народне пјесме, Скупио их и на свијет издао..., Кюига четврта у којој су пјесме јуначке новијих времена о војевану за слободу, у Бечу 1862. Наводи по: Сабрана дела 
Вука Караиића, књига седма, приредио Љубомир Зуковић, Просвета, Београд, 1986.

СНПр II - Српске народне пјесме из необјављених рукописа Вука Стеф. Карачића, књига друга, Пјесме јуначке најстарије, за штампу приредили Живомир Младеновић и Владан Недић, Београд, 1974.

* Рад је претходно објављен у зборнику Научни састанак слависта у Вукове дане, 26/1, 185-192 